\title{
Turock urges support for equity
}

No ones knows better than college and university librarians that the information superhighway is not about the future; it's about now. You have been at the cutting edge of information technology for decades struggling to keep students and scholars current in their disciplines. But the public is not nearly as well versed. When asked by an AT\&T survey team, "Can you help me find the information super-

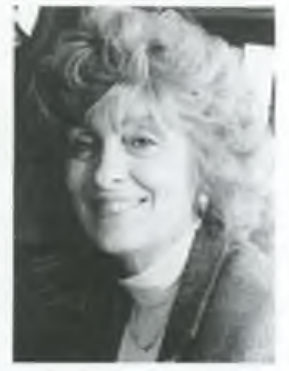

Betty Turock highway?" members of the public responded, "Just turn left on Forty-Second Street" and "I travel it all the time, but I can't tell you how to get there from here." Decisions are being made now by legislators and policy-makers that will affect the quality of library service in higher education well into the next century. Unless we take on the job of informing the American public what is at stake, those decisions will be made without informed public participationand they may not be the decisions we desire. As part of ALA Goal 2000, I have focused my year as president on ensuring that all libraries are major access points to the information su- perhighway. I am meeting with media in 10 cities to take this message to the American people. I will also host a summit called "A Nation Connected: Defining the Public Interest in the Information Superhighway" that I hope will become a model for other such discussions. But I cannot do it alone. I need-ALA needscollege and university librarians to play a leadership role in achieving ALA Goal 2000. As members of ACRL, you have already made a strong financial contribution. But ALA cannot succeed without your individual commitment as well. We need you to:

- become members of the Library Advocacy Now! Network and to provide advocacy training for academic librarians;

- urge administrators to make information technology a priority for libraries;

- visit or write state legislators and Congressional representatives to urge their support for libraries on the information superhighway;

- sponsor a summit on your campus;

- participate in "Log on @ the Library Day";

- collect signatures for the Equity Petition.

Our libraries need your commitment now. Together we must make certain that librarians are partners in designing, implementing, organizing, and navigating the information superhighway.-Betty J. Turock, President, ALA

\section{Prizes offered for NLW media placements}

The 1996 observance of National Library Week (NLW), April 14-20, continues the theme "Libraries Change Lives" with the addition of a tagline - "Call. Visit. Log on."-to highlight the role of libraries in making information technology available to the public. This is the fourth year for the theme that the NLW Committee claims has been the most popular-and powerful-ever.

To focus attention on how technology is helping libraries change lives, ALA will award an Encarta 96 Encyclopedia Multimedia CDROM (retail value \$54.95), compliments of Microsoft, to every library that submits a story, editorial, column, or interview carried by nonlibrary media-newspapers, magazines, newsletters, radio, or TV-about how the public is benefitting from computers, the Internet, and other information technology at the library.
A grand prize, consisting of a complete Microsoft CD-ROM library-more than 30 products (retail value $\$ 1,300$ ) -will be awarded for the best placement. The top 10 entries will receive the Microsoft Reference Library (retail value $\$ 164.85$ ). All types of libraries are eligible to enter.

Placements must appear after January 1 1996, in nonlibrary media. Copies of articles or tapes (audiocassette or VHS videotape) should be submitted by May 10 to the ALA Public Information Office, $50 \mathrm{E}$. Huron St., Chicago, IL 60611, along with a letter documenting how the placement originated and contact information for the library. A certificate will be given to the local media that published/aired the story. For more information, contact the ALA / PIO at (312) 280-5044/5040; fax: (312) 944-8620; e-mail: pio@ala.org. 


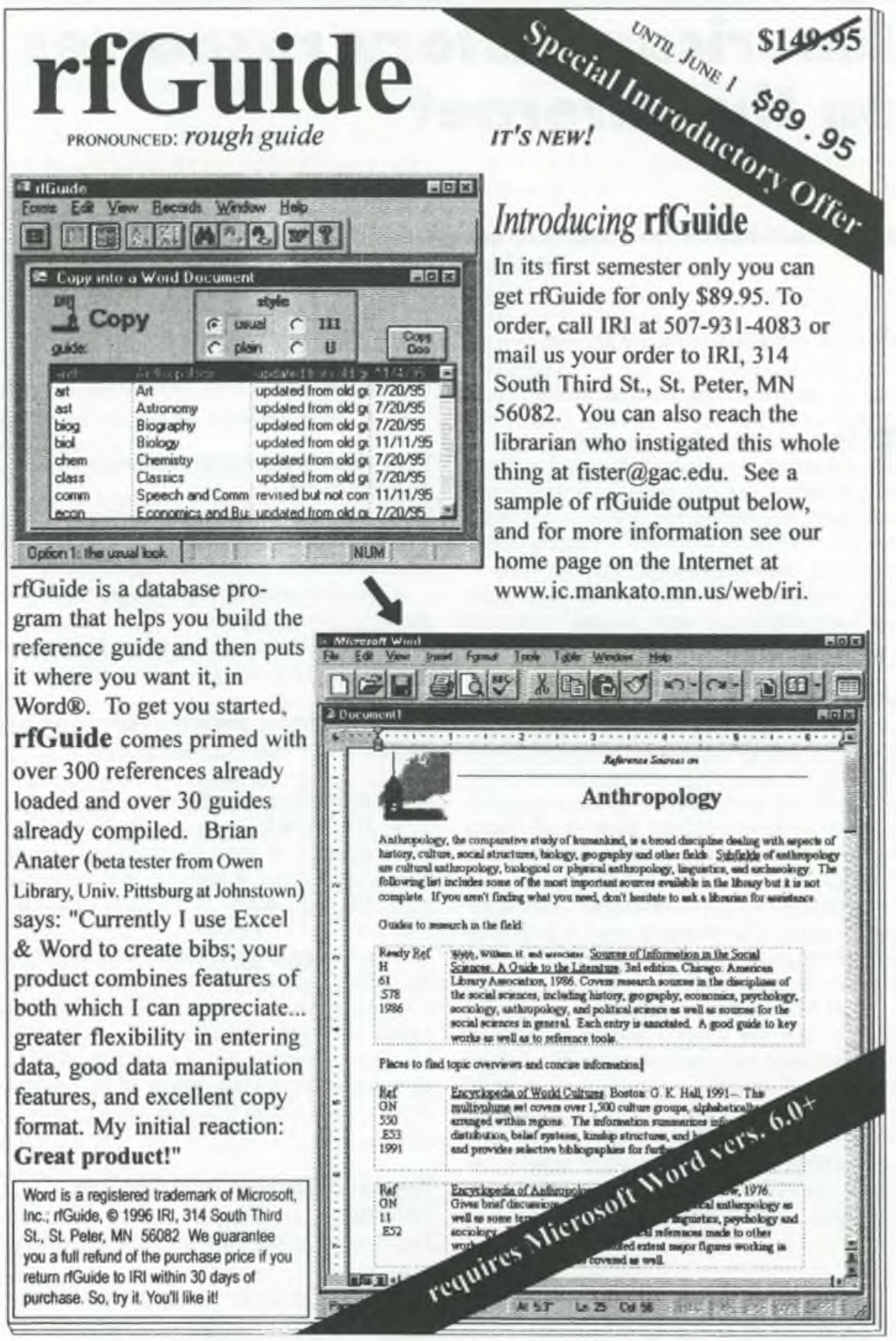

